\title{
PENYELESAIAN SENGKETA LINGKUNGAN MELALUI PERADILAN TATA USAHA NEGARA
}

\author{
A'an Effendi \\ Fakultas Hukum Universitas Negeri Jember \\ e-mail: effendi_hukum@yahoo.com
}

\begin{abstract}
ABSTRAK
Penyelesaian sengketa lingkungan melalui peradilan tata usaha negara adalah dengan mengajukan gugatan di pengadilan peradilan tata usaha negara dengan tujuan agar supaya hakim membatalkan penerbitan izin lingkungan yang tidak cermat, sehingga dapat menghentikan dengan segera pencemaran lingkungan yang terjadi. Penyelesaian sengketa lingkungan melalui peradilan tata usaha negara berfungsi untuk menghentikan pencemaran lingkungan yang terjadi melalui prosedur hukum administrasi. Dasar hukum gugatan sengketa lingkungan melalui peradilan tata usaha negara mengacu kepada Undang-Undang No. 32 Tahun 2009 tentang Perlindungan dan Pengelolaan Lingkungan Hidup dan Undang-Undang Peradilan Tata Usaha Negara.

Kata Kunci: penyelesaian sengketa lingkungan, peradilan tata usaha negara.

ABSTRACT

Environmental dispute resolution through the administrative courts is done by submitting lawsuit into administrative courts in order the judge will cancel the issuance of environmental permits which were not carefully made, so that it could stop the environment pollution which occurred immediately. Environmental dispute resolution through administrative courts aims to stop the environment pollution which occurred through administrative law procedures. The legal basis for the lawsuit of environmental dispute resolution through administrative courts refers to the Law No. 32/2009 about the Environment Protection and Management and also Administrative Court Law.
\end{abstract}

Keywords: environmental dispute, administrative court.

\section{PENDAHULUAN}

Dalam rangka adanya pengendalian pencemaran lingkungan, kelembagaan yang berwenang melakukan upaya akan pencegahan dan penanggulangan dampak negatif serta pemulihan kualitas sangat berperan (Siti Sundari Rangkuti, 1994:4). Kelembagaan yang berwenang dalam pengelolaan lingkungan mencakup tingkat pusat dan daerah. Kelembagaan pengelolaan lingkungan tingkat daerah sangat penting, mengingat pencemaran dan perusakan lingkungan terjadinya di daerah yang memerlukan tindakan penanggulangan yang bersifat segera. Kelembagaan yang berwenang dalam pengelolaan lingkungan adalah kunci pokok keberhasilan pengelolaan lingkungan. Dalam UndangUndang No. 32 Tahun 2009 tentang Perlindungan dan Pengelolaan Lingkungan Hidup (UUPPLH), wewenang dan kelembagaan pengelolaan lingkungan diatur dalam Bab IX Pasal 63 sampai dengan Pasal 64 (Majalah Ilmiah Hukum dan Masyarakat, No.III/ TH.XXXIV/2009).

Wewenang dan juga kelembagaan pengelolaan lingkungan di tingkat nasional dan daerah secara konkrit adalah kewenangan untuk menerbitkan izin lingkungan. Izin lingkungan adalah instrumen yang berfungsi sebagai sarana pencegahan pencemaran lingkungan (Jurnal Ilmu Hukum Qistie, Vol.3 No.3, 2009:70). Izin lingkungan dikeluarkan oleh badan atau pejabat yang berwenang dalam bentuk keputusan atau ketetapan yang menurut Undang-Undang No. 51 Tahun 2009 mengenai Perubahan Kedua atas Undang-Undang No. 5 Tahun 1986 tentang Peradilan Tata Usaha Negara (yang selanjutnya disebut UU PERATUN) disebut Keputusan Tata Usaha Negara (yang selanjutnya disebut KTUN). KTUN adalah suatu penetapan tertulis yang dikeluarkan oleh Badan atau Pejabat Tata Usaha Negara yang berisi tindakan hukum tata usaha negara yang berdasarkan peraturan perundang-undangan yang berlaku, yang bersifat konkret, individual, dan final, yang menimbulkan akibat hukum bagi seseorang atau juga badan hukum perdata (Pasal 1 angka 3 UU PERATUN).

Dalam prakteknya terkadang penerbitan suatu KTUN dapat juga menimbulkan kerugian terhadap 
masyarakat karena adanya suatu unsur kesalahan atau kekeliruan. Diterbitkannya KTUN oleh badan atau pejabat berwenang yang mengandung unsur kesalahan, contohnya kesalahan menerbitkan izin lingkungan sehingga mengakibatkan pencemaran lingkungan, bagi pihak yang dirugikan dapat untuk mengajukan gugatan di peradilan tata usaha negara, agar KTUN (izin lingkungan) tersebut dibatalkan atau dinyatakan tidak sah. Gugatan oleh seseorang atau badan hukum perdata yang merasa kepentingannya dirugikan ke peradilan tata usaha negara adalah berisi tuntutan agar izin itu dinyatakan batal atau tidak sah oleh hakim, sehingga putusan tersebut segera menghentikan pencemaran akibat izin lingkungan yang mana tidak dibuat dengan cermat (Siti Sundari Rangkuti, 2008:121).

Prosedur gugatan terhadap KTUN yang berwujud izin lingkungan sebagai suatu sarana penyelesaian sengketa lingkungan yang administatif (Siti Sundari Rangkuti, 1991:5) dengan melalui peradilan tata usaha negara pada awalnya tidak diatur dalam peraturan perundang-undangan lingkungan yang berlaku saat ini, yaitu Undang-Undang No. 4 Tahun 1982 tentang Ketentuan-Ketentuan Pokok Pengelolaan Lingkungan Hidup (yang selanjutnya disebut UUPLH) maupun undang-undang penggantinya, Undang-Undang No. 23 Tahun 1997 tentang Pengelolaan Lingkungan Hidup (yang selanjutnya akan disingkat UUPLH). Meskipun demikian, ada beberapa kasus lingkungan telah diajukan ke Pengadilan Tata Usaha Negara sebelum diundangkannya UUPPLH, yaitu: gugatan yang diajukan oleh WALHI, Yayasan Forum Studi Kependudukan dan juga Lingkungan Hidup, Yayasan Pengembangan Hukum Lingkungan dan Yayasan Forum Studi Kependudukan dan Lingkungan Hidup terhadap Presiden akibat dikeluarkannya Keppres No. 42 Tahun 1994 tentang Bantuan Pinjaman yang Berasal dari Dana Reboisasi kepada PT IPTN dan gugatan dari WALHI melalui Pengadilan Tata Usaha Negara DKI terhadap Sekretaris Jenderal Departemen Pertambangan dan Energi, karena telah mengeluarkan Surat No. 600/6115/SJT/1995 tentang Persetujuan Laporan RKL dan juga RPL PT Freeport Indonesia Company (Takdir Rahmadi, 2003:149-150).

Setelah diberlakukannya UUPPLH, dasar hukum gugatan terhadap izin lingkungan melalui peradilan tata usaha negara tertuang dalam ketentuan Pasal 93 tentang Gugatan Administratif. Diaturnya mekanisme penyelesaian sengketa lingkungan melalui peradilan tata usaha negara didalam UUPPLH merupakan suatu kemajuan di bidang hukum lingkungan, mengingat sebagian besar hukum lingkungan adalah hukum administrasi. Pada masa mendatang perlu dilakukan pemberdayaan peradilan tata usaha negara sebagai sarana penyelesaian suatu sengketa lingkungan untuk menghentikan pencemaran lingkungan akibat suatu izin lingkungan (hukum lingkungan administratif) (Siti Sundari Rangkuti, 2008:123).

Tulisan ini mengkaji secara teoritis penyelesaian sengketa lingkungan melalui peradilan tata usaha negara berdasarkan UUPLH dan UU PERATUN serta prakteknya dalam gugatan sengketa lingkungan di peradilan tata usaha negara.

\section{PEMBAHASAN \\ Penyelesaian Sengketa Lingkungan Melalui Badan Peradilan Tata Usaha Negara}

Dasar hukum gugatan sengketa lingkungan di peradilan tata usaha negara diatur dalam ketentuan Pasal 93 yaitu sebagai berikut: 1 . Setiap orang dapat mengajukan gugatan terhadap keputusan tata usaha negara apabila: a. Badan atau pejabat tata usaha negara menerbitkan izin lingkungan kepada usaha dan/atau kegiatan yang wajib amdal tetapi tidak dilengkapi dengan dokumen amdal; $b$. Badan atau pejabat tata usaha negara menerbitkan izin lingkungan kepada kegiatan yang wajib untuk UKL-UPL, tetapi tidak dilengkapi dengan dokumen UKL-UPL; dan/atau c. Badan atau pejabat TUN yang menerbitkan izin usaha dan/atau kegiatan yang tidak dilengkapi dengan izin lingkungan. 2. Tata cara pengajuan terhadap keputusan tata usaha negara mengacu pada Hukum Acara Peradilan Tata Usaha Negara.

Gugatan sengketa lingkungan di peradilan tata usaha negara mengacu pada hukum acara peradilan tata usaha negara, yaitu hukum acara peradilan tata usaha negara sebagaimana di atur dalam UndangUndang No. 5 Tahun 1986 tentang Peradilan Tata Usaha Negara sebagaimana telah diubah dua kali dengan Undang-Undang No. 9 Tahun 2004 tentang Perubahan atas Undang-Undang No. 5 Tahun 1986 tentang Peradilan Tata Usaha Negara dan UndangUndang No. 51 Tahun 2009 tentang Perubahan Kedua terhadap Undang-Undang No. 5 Tahun 1986 tentang Peradilan Tata Usaha Negara (UU PERATUN).

Ketentuan Pasal 93 UUPPLH yang menyatakan setiap orang dapat mengajukan gugatan terhadap keputusan tata usaha negara, bukanlah berarti siapa saja dapat menjadi pihak penggugat dalam sengketa lingkungan di peradilan tata usaha negara. Pengertian setiap orang ini harus dihubungkan dengan pengertian sengketa tata usaha negara dan juga pengertian dari KTUN sebagai suatu obyek sengketa di peradilan tata usaha negara. 
Pasal 1 angka 4 UU PERATUN menyatakan: Sengketa tata usaha negara adalah sengketa yang timbul dalam bidang tata usaha negara antara orang atau badan hukum perdata dengan Badan atau Pejabat Tata Usaha Negara, baik di pusat maupun di daerah, sebagai akibat dikeluarkannya Keputusan Tata Usaha Negara, termasuk sengketa kepegawaian berdasarkan peraturan perundang-undangan. Berdasarkan Pasal 1 angka 4 UU PERATUN, subyek suatu sengketa tata usaha negara adalah orang atau juga badan hukum perdata melawan badan atau pejabat tata usaha negara sebagai akibat dikeluarkannya keputusan tata usaha negara. Orang atau badan hukum perdata bertindak sebagai pihak penggugat yang menggugat badan atau pejabat tata usaha negara yang mengeluarkan KTUN sebagai pihak tergugat. KTUN adalah obyek sengketa di peradilan tata usaha negara. KTUN adalah suatu penetapan tertulis yang dikeluarkan oleh badan atau pejabat tata usaha negara yang berisi tindakan hukum tata usaha negara yang berdasarkan peraturan perundang-undangan yang berlaku, yang bersifat konkret, individual dan final, yang menimbulkan akibat hukum bagi seseorang atau juga badan hukum perdata (Pasal 1 angka 3). Tanpa KTUN tidak ada sengketa tata usaha negara.

Mengenai kedudukan orang atau badan hukum perdata sebagai pihak penggugat dalam sengketa tata usaha negara dijelaskan oleh Pasal 53 ayat 1 UU PERATUN: Orang atau badan hukum perdata yang merasa kepentingannya dirugikan oleh suatu Keputusan Tata Usaha Negara dapat mengajukan gugatan tertulis kepada pengadilan yang berwenang yang berisi klausula tuntutan agar Keputusan Tata Usaha Negara yang disengketakan itu dinyatakan batal atau tidak sah, dengan atau tanpa disertai tuntutan ganti rugi dan/atau rehabilitasi.

Penjelasan Pasal 53 ayat 1 UU PERATUN: Sesuai dengan ketentuan Pasal 1 angka 4 maka hanya orang atau badan hukum perdata yang berkedudukan sebagai subyek hukum saja yang dapat mengajukan gugatan ke Pengadilan Tata Usaha Negara untuk menggugat Keputusan Tata Usaha Negara. Selanjutnya hanya orang atau badan hukum perdata yang kepentingannya terkena oleh akibat hukum Keputusan Tata Usaha Negara yang mana dikeluarkan dan karenanya itu yang bersangkutan merasa dirugikan itu dibolehkan menggugat Keputusan Tata Usaha Negara.

Kedudukan badan atau pejabat tata usaha negara sebagai tergugat ditentukan oleh Pasal 1 angka 6 yang menyatakan: Tergugat adalah Badan atau Pejabat Tata Usaha Negara yang mengeluarkan keputusan berdasarkan wewenang yang ada padanya atau yang dilimpahkan kepadanya, yang digugat oleh orang atau badan hukum perdata.

Setiap orang yang dimaksud oleh Pasal 93 ayat 1 UUPPLH adalah orang atau badan hukum perdata yang kepentingannya dirugikan oleh KTUN yang dikeluarkan oleh badan atau pejabat tata usaha negara. Orang atau badan hukum perdata inilah yang menjadi pihak penggugat dalam kasus sengketa lingkungan di peradilan tata usaha negara.

Orang atau juga badan hukum perdata ini dapat mengajukan gugatan terhadap KTUN di pengadilan tata usaha negara dengan alasan-alasan: KTUN yang digugat itu bertentangan dengan peraturan perundangundangan yang berlaku; KTUN yang digugat itu bertentangan dengan asas-asas umum pemerintahan yang baik (Pasal 53 ayat 2 UU PERATUN).

Menurut penjelasan dalam Pasal 53 ayat 2 UU PERATUN, KTUN yang mana bertentangan dengan peraturan perundang-undangan dapat digolongkan menjadi 2 (dua) macam, yaitu bertentangan dengan peraturan perundang-undangan secara prosedural atau formal dan bertentangan dengan peraturan perundangundangan secara materiil atau substantif.

Berdasarkan pada ketentuan dalam Pasal 93 ayat 1 UUPPLH, gugatan terhadap KTUN yang berwujud izin lingkungan dapat dilakukan dengan alasan-alasan: 1. Badan atau pejabat tata usaha negara menerbitkan izin lingkungan pada usaha dan/atau kegiatan yang wajib amdal tetapi tidak dilengkapi dengan dokumen amdal; 2. Badan atau juga pejabat tata usaha negara menerbitkan izin lingkungan kepada kegiatan yang wajib UKL-UPL, tetapi tidak dilengkapi dengan dokumen UKL-UPL; dan/atau 3. Badan atau pejabat tata usaha negara yang menerbitkan izin usaha dan/ atau kegiatan yang mana tidak dilengkapi dengan suatu izin lingkungan.

Ketentuan Pasal 93 ayat 1 UUPPLH ini harus dihubungkan dengan ketentuan Pasal 53 ayat 1 dan ayat 2 UU PERATUN. Apabila dengan diterbitkannya KTUN (izin lingkungan) merugian kepentingan orang atau juga badan hukum perdata maka dapat diajukan gugatan di peradilan tata usaha negara dengan alasanalasan sebagaimana disebut oleh Pasal 53 ayat 2 agar KTUN (izin lingkungan) itu dinyatakan batal atau tidak sah dengan atau tanpa disertai ganti kerugian. Artinya, meskipun izin lingkungan yang diterbitkan kepada usaha dan/atau kegiatan yang wajib amdal dan dilengkapi dengan dokumen amdal atau izin lingkungan yang diterbitkan kepada kegiatan yang wajib UKL-UPL dan dilengkapi dengan UKL-UPL ataupun suatu izin usaha yang dilengkapi dengan izin lingkungan, namun apabila dengan diterbitkannya izin 
lingkungan ini menyebabkan terjadinya pencemaran lingkungan sehingga merugikan kepentingan orang atau badan hukum perdata maka dapatlah diajukan gugatan di badan peradilan tata usaha negara agar izin lingkungan itu dinyatakan batal atau tidak sah.

Secara lebih jelas, orang atau badan hukum perdata dapat menggugat suatu KTUN yang mana merugikan kepentingannya ke peradilan tata usaha negara dengan alasan KTUN itu bertentangan dengan peraturan perundang-undangan yang berlaku atau KTUN itu bertentangan dengan AUPB. Maka dengan demikian, sepanjang KTUN itu merugikan kepentingan orang atau badan hukum perdata, namun tidak terpenuhi ketentuan sebagaimana ditetapkan oleh Pasal 93 ayat 1 UUPPLH, orang atau badan hukum perdata tetap dapat menggugatnya di peradilan tata usaha negara karena KTUN yang digugat itu bertentangan dengan peraturan perundang-undangan yang berlaku atau bertentangan dengan AUPB.

Penyelesaian dari sengketa lingkungan melalui badan peradilan tata usaha negara memiliki kelebihankelebihan bila dibandingkan dengan penyelesaian sengketa lingkungan di peradilan umum, baik itu melalui gugatan perdata maupun tuntutan secara pidana. Gugatan perdata di peradilan umum tujuannya adalah untuk memperoleh ganti kerugian bagi korban pencemaran atau juga perusakan lingkungan yang tentunya tidak menyentuh persoalan perbuatannya (pencemarannya). Tuntutan pidana ditujukan kepada pelakunya (pencemarnya) dan juga tidak menyentuh perbuatannya (pencemarannya). Gugatan perdata atau tuntutan di badan peradilan umum itu tidak untuk menyelesaikan persoalan pencemarannya sendiri.

Dengan adanya gugatan sengketa lingkungan di peradilan tata usaha negara adalah bertujuan untuk membatalkan izin lingkungan yang dimiliki oleh suatu usaha dan/atau kegiatan. Dengan dibatalkannya izin lingkungan tersebut berarti suatu usaha atau kegiatan tidak dapat melanjutkan lagi usaha atau kegiatannya sehingga sumber pencemarannya dapat dihentikan. Sasaran yang dituju disini adalah aspek perbuatannya (pencemarannya). Gugatan terhadap izin lingkungan di peradilan tata usaha bertujuan untuk menghentikan pencemaran yang terjadi.

\section{Praktek Adanya Gugatan Sengketa Lingkungan di Peradilan Tata Usaha Negara}

Gugatan dari lembaga WALHI, Yayasan Forum Studi Kependudukan dan juga Lingkungan Hidup, Yayasan Pengembangan Hukum Lingkungan dan Yayasan Forum Studi Kependudukan dan Lingkungan Hidup terhadap Presiden akibat dari dikeluarkannya
Keputusan Presiden No. 42 Tahun 1994 mengenai Bantuan Pinjaman yang Berasal dari Dana Reboisasi Kepada PT IPTN.

Empat pihak Lembaga Swadaya Masyarakat (yang selanjutnya disebut LSM) yaitu WALHI, Yayasan Forum Studi Kependudukan dan Lingkungan Hidup, Yayasan Pengembangan Hukum Lingkungan dan Yayasan Forum Studi Kependudukan dan Lingkungan Hidup telah mengajukan gugatan terhadap Presiden akibat dikeluarkannya Keputusan Presiden (yang selanjutnya disebut Keppres) No. 42 Tahun 1994 tentang Bantuan Pinjaman yang Berasal dari Dana Reboisasi kepada PT.IPTN. Keppres tersebut menurut para penggugat dinilai bertentangan dengan peraturan perundang-undangan dan juga lingkungan. Namun, majelis hakim pada Pengadilan Tata Usaha Negara DKI Jakarta (Putusan No. 008/G/1994) memutuskan bahwa gugatan dari keempat LSM itu tidak diterima karena Keppres No. 42 Tahun 1994 belum bersifat final, sehingga tidak memenuhi pengertian KTUN menurut UU PERATUN. Dalam kasus ini majelis hakim pada Pengadilan Tata Usaha Negara mengakui kewenangan dari LSM di bidang lingkungan untuk mengajukan gugatan TUN dengan prasyarat LSM itu merupakan sebuah badan hukum, memiliki anggaran dasar dengan tujuan perlindungan lingkungan dan nyata-nyata berbuat untuk perlindungan lingkungan hidup (Takdir Rahmadi, 2003:149-150)

Meskipun gugatannya itu tidak diterima namun segi positif dari putusan pengadilan di atas adalah diakuinya suatu legal standing bagi LSM lingkungan. Dengan diberikannya legal standing tersebut maka LSM lingkungan dapat tampil sebagai penggugat dalam kasus-kasus lingkungan. Putusan pengadilan yang sebelumnya juga mengakui legal standing LSM lingkungan hidup adalah Putusan Majelis Hakim PN Jakarta Pusat (Putusan No. 820/PDT.G/1998) dalam kasus kerusakan hutan dimana WALHI tampil sebagai penggugat yang menggugat Kepala Badan Koordinasi Penanaman Modal, Menteri Dalam Negeri, Gubernur Sumatera Utara, Menteri Perindustrian, juga Menteri Negara Kependudukan dan Lingkungan Hidup, juga Menteri Kehutanan, dan PT Inti Indorayon Utama.

Gugatan WALHI diajukan melalui Pengadilan Tata Usaha Negara DKI terhadap Sekretaris Jenderal Departemen Pertambangan dan Energi, karena Telah Mengeluarkan Surat No. 600/6115/SJT/1995 tentang Persetujuan Laporan RKL dan RPL PT Freeport Indonesia Company.

WALHI melalui Pengadilan Tata Usaha Negara DKI menggugat Sekretaris Jenderal Departemen Pertambangan dan Energi, karena telah mengeluarkan 
Surat No. 600/6115/SJT/1995 tentang Persetujuan Laporan RKL dan RPL dari PT.Freeport Indonesia Company. WALHI telah menilai bahwa pengeluaran dari surat persetujuan itu mengabaikan saran-saran WALHI selaku anggota tidak tetap Komisi AMDAL Departemen Pertambangan dan Energi. Tergugat telah mengajukan eksepsi, antara lain: bahwa surat persetujuan tentang RKL dan RPL bukanlah sebuah keputusan TUN tetapi hanya surat biasa. Oleh sebab itu, gugatan seharusnya harus dinyatakan tidak dapat diterima. Majelis hakim menolak eksepsi ini. Akan tetapi dalam pokok perkara, majelis hakim (Putusan: 053/G/1995/PTUN Jkt) menolak gugatan WALHI atas dasar, bahwa diikuti atau tidaknya saran-saraan WALHI adalah merupakan kewenangan dicreationer dari Komisi AMDAL. Dengan kata lain, anggotaanggota lainnya dalam Komisi AMDAL tidak terikat dengan saran-saran pihak WALHI dalam memberikan persetujuan atas dokumen RKL dan RPL.

Hal yang menarik dari kasus yang kedua adalah digugatnya sebuah dokumen AMDAL yang mana AMDAL itu adalah bagian dari prosedur perizinan dengan demikian AMDAL bukanlah sebuah KTUN yang didalamnya terkandung unsur-unsur: tertulis, konkrit, individual dan final (Siti Sundari Rangkuti, 2005:134-135). Yang mempunyai kedudukan sebagai KTUN adalah izin. Dengan demikian yang dapat diajukan gugatan ke PTUN adalah izinnya bukan AMDALnya. Dalam prakteknya AMDAL instansi yang bertanggungjawab hanya sekedar rekomendasi (Suparto Wijoyo, 1999:61).

Gugatan Enam Orang Pengusaha terhadap Menteri Negara Lingkungan Hidup dengan Obyek Sengketa adalah Surat Keputusan Menteri Negara Lingkungan Hidup No. 14 Tahun 2003 tentang Ketidaklayakan Rencana Kegiatan Reklamasi dan Revitalisasi Pantai Utara Jakarta

Tjondro Indria Liemonta bertindak untuk dan atas nama PT Bakti Bangun Era Mulia, Ir. Richard S. Hartono dan Ir. Suhendro Prabowo bertindak untuk dan atas nama PT Taman Harapan Indah, Ir. Aris Setyanto Nugroho dan Susanto bertindak untuk dan atas nama PT Manggala, A. Syaifuddin bertindak untuk atas nama PT (Persero) Pelabuhan Indonesia II, Ir. Jahja B. Riabudi, MBA bertindak untuk dan atas nama PT Pembangunan Jaya Ancol dan Ir. H. Ongki Sukasah H. bertindak untuk dan atas nama PT Jakarta Propetindo menggugat Menteri Negara Lingkungan Hidup sebagai akibat dikeluarkannya Surat Keputusan Menteri Negara Lingkungan Hidup No. 14 Tahun 2003 tentang Ketidaklayakan dari Rencana Kegiatan Reklamasi dan Revitalisasi Pantai Utara Jakarta.
Adapun latar belakang, argumentasi dan dasar hukum dari gugatan penggugat atau fundamentum petendi yang pada pokoknya bahwa pada tanggal 19 Februari 2003, tergugat telah mengeluarkan Surat Keputusan Menteri Negara Lingkungan Hidup No. 14 Tahun 2003 tentang Ketidaklayakan Rencana Kegiatan Reklamasi dan Revitalisasi Pantai Utara Jakarta oleh Badan Pelaksana Reklamasi Pantai Utara Jakarta di Propinsi DKI Jakarta, yang pada pokonya mewajibkan kepada semua instansi yang berwenang untuk menolak permohonan izin melakukan usaha dan atau kegiatan yang berhubungan dengan reklamasi dan revitalisasi tersebut.

Bahwa sebagai akibat daripada dikeluarkannya keputusan a quo, para penggugat telah mengalami kerugian materiel dan immateriel, dengan perincian dari masing-masing pihak akan disampaikan sebagai lampiran dalam bukti para penggugat. Bahwa Surat Keputusan Menteri Negara Lingkungan Hidup No. 14 Tahun 2003 tentang Ketidaklayakan Rencana Kegiatan Reklamasi dan Revitalisasi Pantai Utara Jakarta itu adalah bertentangan dengan peraturan perundang-undangan yang berlaku.

Bahwa penerbitan dari Surat Keputusan Menteri Negara Lingkungan Hidup No.14 Tahun 2003 tentang Ketidaklayakan Rencana Kegiatan Reklamasi dan Revitalisasi dari Pantai Utara Jakarta oleh tergugat merupakan perbuatan melampaui wewenang atau Detournement de Pouvoir, karena menyimpang dari maksud dan tujuan wewenangnya. Bahwa penerbitan Surat Keputusan Menteri Negara Lingkungan Hidup No. 14 Tahun 2003 tentang Ketidaklayakan Rencana Kegiatan Reklamasi dan Revitalisasi Pantai Utara Jakarta oleh tergugat merupakan perbuatan sewenangwenang atau Willekeur, karena tidak sesuai dengan fakta-fakta yang sebenarnya. Bahwa berdasarkan hal-hal tersebut di atas penggugat mohon kepada Pengadilan Tata Usaha Negara supaya memberikan putusan sebagai berikut:

DALAM PROVISI (PENUNDAAN):

Memerintahkan Tergugat untuk menunda berlakunya keputusan Tergugat No. 14 Tahun 2003 tanggal 19 Februari 2003 tentang Ketidaklayakan Rencana Kegiatan Reklamasi dan Revitalisasi Pantai Utara Jakarta oleh Badan Pelaksana Pantai Utara Jakarta di Propinsi Daerah Khusus Ibukota Jakarta dan produk administrative lainnya sampai menunggu adanya keputusan yang berkekuatan tetap.

DALAM POKOK PERKARA:

1. Mengabulkan gugatan Para Penggugat untuk seluruhnya;

2. Menyatakan batal atau tidak sah Surat Keputusan Tergugat No. 14 Tahun 2003 tanggal 19 Februari 2003 tentang Ketidaklayakan Rencana Kegiatan Reklamasi dan Revitalisasi Pantai Utara Jakarta oleh Badan Pelaksana Pantai Utara Jakarta di Propinsi Daerah Khusus Ibukota 
Jakarta;

3. Mewajibkan dan memerintahkan Tergugat untuk mencabut Surat Keputusan Tergugat No. 14 Tahun 2003 tanggal 19 Februari 2003 tentang Ketidaklayakan Rencana Kegiatan Reklamasi dan Revitalisasi Pantai Utara Jakarta oleh Badan Pelaksana Pantai Utara Jakarta di Propinsi Daerah Khusus Ibukota Jakarta;

4. Menghukum Tergugat untuk membayar biaya perkara yang timbul dalam perkara ini;

Apabila Pengadilan berpendapat lain, mohon putusan yang seadil-adilnya (ex aequo et bono).

Tergugat mengajukan eksepsi sebagai berikut:

I. Mengenai Kompetensi Absolut;

Bahwa surat keputusan yang dikeluarkan oleh tergugat bukanlah Keputusan Tata Usaha Negara sebagaimana dimaksud Pasal 1 angka 3 Undang-Undang No. 5 Tahun 1986, karena masih bersifat rekomendasi dan belum bersifat final.

II. Eksepsi lain-lain;

A. Para penggugat tidak memiliki kepentingan hukum dalam mengajukan gugatan a quo (Standi in Persona);

B. Gugatan salah alamat (Error in Persona);

C. Gugatan penggugat kabur (Obscuur Libel);

D. Keputusan tergugat a quo tidak bersifat individual dan final;

Amar Putusan Pengadilan Tata Usaha Negara No. 75/G.TUN/2003/PTUN-JKT tanggal 11 Februari 2003 sebagai berikut:

\section{DALAM POKOK PERKARA:}

1. Mengabulkan gugatan Para Penggugat untuk seluruhnya;

2. Menyatakan tidak sah Surat Keputusan Tergugat No. 14 Tahun 2003 tanggal 19 Februari 2003 tentang Ketidaklayakan Rencana Kegiatan Reklamasi dan Revitalisasi Pantai Utara Jakarta oleh Badan Pelaksana Pantai Utara Jakarta di Propinsi Daerah Khusus Ibukota Jakarta;

3. Mewajibkan kepada Tergugat untuk mencabut Surat Keputusan Tergugat No. 14 Tahun 2003 tanggal 19 Februari 2003 tentang Ketidaklayakan Rencana Kegiatan Reklamasi dan Revitalisasi Pantai Utara Jakarta oleh Badan Pelaksana Pantai Utara Jakarta di Propinsi Daerah Khusus Ibukota Jakarta;

4. Memerintahkan kepada Tergugat untuk menunda pelaksanaan dan tindaklanjut berlakunya Surat Keputusan No. 14 Tahun 2003 tanggal 19 Februari 2003 sampai adanya putusan yang mempunyai kekuatan hukum tetap;

5. Menghukum Para Tergugat secara tanggung renteng untuk membayar biaya perkara yang besarnya Rp162.000,00 (seratus enam puluh dua ribu rupiah);

Terhadap putusan Pengadilan Tata Usaha Negara Jakarta tersebut diajukan banding oleh pihak Tergugat kepada Ketua Pengadilan Tinggi Tata Usaha Negara. Pengadilan Tinggi Tata Usaha Negara Jakarta dengan Putusan No. 202/B/2004/PT.TUN.JKT. tanggal 3 Februari 2005 yang amarnya sebagai berikut:

\section{DALAM PUTUSAN SELA:}

- Menerima permohonan banding dari Tergugat atau Pembanding mengenai Putusan Sela;
- Menguatkan Putusan Sela Putusan Pengadilan Tata Usaha Negara Jakarta No. 75/G.TUN/2003/PTUNJKT, tanggal 23 September 2003, yang dimohonkan Banding;

II. DALAM PUTUSAN AKHIR:

DALAM EKSEPSI:

- Menolak Eksepsi dari Tergugat atau Pembanding seluruhnya;

DALAM POKOK PERKARA:

- Menerima Permohonan Banding dari Tergugat atau Pembanding, Para Tergugat II Intervensi atau Para Pembanding;

- Menguatkan Putusan Pengadilan Tata Usaha Negara Jakarta No. 75/G.TUN/2003/PTUN-JKT, tanggal 11 Februari 2004, yang dimohonkan Banding;

- Menghukum Tergugat atau Pembanding, Para Tergugat II Intervensi atau Para Pembanding untuk membayar biaya perkara secara bersama-sama, yang dalam Tingkat Banding ditetapkan sebesar Rp200.000,00 (dua ratus ribu rupiah);

Terhadap putusan Pengadilan Tinggi Tata Usaha Negara ini diajukan kasasi oleh Tergugat/Pembanding berdasarkan Surat Kuasa Khusus tanggal 23 Juni 2003 dan Surat Kuasa Khusus Substitusi tanggal 4 Juli 2003 diajukan permohonan kasasi secara lisan pada tanggal 25 April 2005 sebagaimana ternyata dari Akte Permohonan Kasasi No. 038/KAS-2005/PTUN-JKT, yang dibuat oleh Panitera Pengadilan Tata Usaha Negara Jakarta.

Pada pemeriksaan tingkat kasasi di Mahkamah Agung yang dilakukan oleh Majelis Hakim yang dipimpin oleh Prof. Dr. Paulus E. Lotulung, S.H. sebagai Ketua Majelis, H. Imam Soebechi, S.H., M.H., dan Marina Sidabutar, S.H., M.H. sebagai anggota, Mahkamah Agung dengan Putusan No.109K/TUN/ 2006, yang amarnya sebagai berikut: Mengabulkan permohonan kasasi dari Pemohon Kasasi: MENTERI NEGARA LINGKUNGAAN HIDUP REPUBLIK INDONESIA tersebut; Membatalkan putusan dari Pengadilan Tinggi Tata Usaha Negara Jakarta No. 202/B/2004/PT.TUN-JKT tanggal 3 Februari 2005 yang menguatkan putusan Pengadilan Tata Usaha Negara Jakarta No. 75/G.TUN/2003/PTUN - JKT tanggal 11 Februari 2004;

Pertimbangan Mahkamah Agung adalah bahwa Surat Keputusan Menteri Negara Lingkungan Hidup No. 14 Tahun 2003 tentang Ketidaklayakan Rencana Kegiatan Reklamasi dan Revitalisasi Pantai Utara Jakarta masih bersifat rekomendasi dan juga belum mempunyai suatu kekuatan hukum karena merupakan bagian atau persyaratan untuk dapat memperoleh ijin dari pejabat yang berwenang. Sehingga surat keputusan a quo belum bersifat final. Oleh karena itu Surat Keputusan in casu bukan merupakan/tidak termasuk dalam pengertian Keputusan Tata Usaha 
Negara menurut ketentuan Pasal 1 angka 2 jo Pasal 2 Huruf c dalam Undang-Undang No. 5 Tahun 1986 sebagaimana diubah dengan Undang-Undang No. 9 Tahun 2004 tentang Peradilan Tata Usaha Negara. Dengan demikian Pengadilan Tata Usaha Negara tidak berwenang untuk memeriksa, memutus dan menyelesaikannya.

Yang menarik untuk kemudian ditelaah dalam kasus reklamasi dan juga revitalisasi Pantai Utara Jakarta di atas adalah mengenai obyek sengketanya, yaitu Surat Keputusan Menteri Negara Lingkungan Hidup No. 14 Tahun 2003 tentang Ketidaklayakan Rencana Kegiatan Reklamasi dan Revitalisasi Pantai Utara Jakarta. Oleh Pengadilan Tata Usaha Negara Jakarta yang kemudian dikuatkan oleh Pengadilan Tinggi Tinggi Tata Usaha Negara surat keputusan ini dikategorikan sebagai KTUN, sehingga menjadi wewenang Pengadilan Tata Usaha Negara Jakarta untuk memeriksa dan menyelesaikannya.

Surat Keputusan Menteri Negara Lingkungan Hidup No. 14 Tahun 2003 tentang Ketidaklayakan Rencana Kegiatan Reklamasi Pantai Utara Jakarta adalah surat keputusan yang berisi penolakan atas dokumen Analisis Mengenai Dampak Lingkungan (yang selanjutnya disebut AMDAL) Reklamasi Pantai Utara Jakarta. Keputusan persetujuan atau penolakan AMDAL tidak dapat dikualifikasi sebagai KTUN, karena tidak terpenuhi unsur menimbulkan akibat hukum sebagaimana disyaratkan oleh Pasal 1 angka 9 UU PERATUN.

AMDAL adalah bagian dari prosedur perizinan, sehingga yang dapat menimbulkan akibat hukum dan juga dapat digugat di Pengadilan Tata Usaha Negara adalah izin lingkungannya bukan dokumen AMDAL nya. Sehingga ini adalah tepat pertimbangan dari Mahkamah Agung yang menyatakan Surat Keputusan Menteri Negara Lingkungan Hidup No. 14 Tahun 2003 mengenai Ketidaklayakan Rencana Kegiatan Reklamasi dan juga Revitalisasi Pantai Utara Jakarta masih bersifat rekomendasi dan belum mempunyai kekuatan hukum karena ini merupakan bagian atau persyaratan untuk memperoleh ijin dari pejabat yang berwenang, sehingga surat keputusan a quo belum bersifat final. Oleh karena itu Surat Keputusan in casu bukan merupakan/tidak termasuk dalam pengertian Keputusan Tata Usaha Negara menurut ketentuan Pasal 1 angka 2 jo Pasal 2 Huruf c Undang-Undang No. 5 Tahun 1986 sebagaimana telah diubah dengan Undang-Undang No. 9 Tahun 2004 tentang Peradilan Tata Usaha Negara. Dengan demikian Pengadilan Tata Usaha Negara tidak berwenang untuk memeriksa, memutus dan menyelesaikannya.
Juga menarik untuk dikaji adalah salah satu amar putusan Pengadilan Tata Usaha Negara Jakarta yang juga dikuatkan oleh Pengadilan Tinggi Tata Usaha Negara Jakarta, yang mana adalah: Memerintahkan kepada Tergugat untuk menunda pelaksanaan dan tindaklanjut berlakunya Surat Keputusan No. 14 Tahun 2003 tanggal 19 Februari 2003 sampai adanya Putusan yang mempunyai kekuatan hukum tetap.

Berdasarkan asas hukum yang berlaku dalam hukum acara peradilan tata usaha negara, yaitu asas praduga rechtmatig (vermoden van rechtmatigheid = praesumptio iustae causa), yang berarti tindakan penguasa harus selalu dianggap sah sampai dengan ada pembatalannya. Konsekuensinya adalah bahwa dengan diajukannya gugatan di Pengadilan Tata Usaha Negara tidak menunda pelaksanaan KTUN yang digugat. Asas praduga rechtmatig ini tertuang dalam ketentuan Pasal 67 UU PERATUN, yaitu Gugatan tidak menunda atau menghalangi dilaksanakannya Keputusan Badan atau Pejabat Tata Usaha Negara serta tindakan Badan atau Pejabat Tata Usaha Negara yang digugat.

Berlakunya suatu asas praduga rechtmatig ini kemungkinan besar dapat merugikan kepentingan penggugat. Misalnya penggugat mengajukan gugatan terhadap KTUN yang berisi perintah penggusuran, selama proses perkara berjalan maka penggusuran akan tetap dilaksanakan karena adanya gugatan di peradilan tata usaha negara tidak menunda berlakunya KTUN yang digugat. Untuk menghindari kerugian semacam itu, pihak penggugat dapat mengajukan permohonan agar pelaksanaan KTUN yang digugat ditunda selama pemeriksaan sengketa TUN sedang berjalan, sampai adanya putusan pengadilan yang memperoleh kekuatan hukum tetap.

Permohonan penundaan pelaksanaan KTUN yang digugat dapat diajukan sekaligus dalam gugatan dan dapat diputus terlebih dahulu dari pokok sengketanya. Permohan penundaan dari pelaksanaan KTUN oleh penggugat dapat dikabulkan hanya apabila terdapat keadaan yang sangat mendesak yang mengakibatkan kepentingan penggugat sangat dirugikan jika KTUN yang digugat tetap dilaksanakan (Pasal 67 ayat 4a) dan permohonan tidak dikabulkan apabila kepentingan umum dalam rangka pembangunan mengharuskan dilaksanakannya keputusan tersebut (Pasal 67 ayat $4 b)$.

\section{PENUTUP \\ Kesimpulan}

Mekanisme penyelesaian sengketa lingkungan melalui badan Peradilan Tata Usaha Negara awal 
mulanya tidak di atur di dalam UULH ataupun di UUPLH dan baru dalam UUPPLH diatur tentang gugatan sengketa lingkungan di peradilan tata usaha negara pada Pasal 93 tentang Gugatan Administratif. Meskipun demikian, ada beberapa kasus lingkungan telah diajukan ke Pengadilan Tata Usaha Negara sebelum diundangkannya UUPPLH, yaitu: gugatan yang diajukan oleh WALHI, Yayasan Forum Studi Kependudukan dan juga Lingkungan Hidup, Yayasan Pengembangan Hukum Lingkungan dan Yayasan Forum Studi Kependudukan dan Lingkungan Hidup terhadap Presiden akibat dikeluarkannya Keppres No. 42 Tahun 1994 tentang Bantuan Pinjaman yang Berasal dari Dana Reboisasi kepada PT IPTN dan gugatan lembaga WALHI melalui Pengadilan Tata Usaha Negara Daerah Khusus Ibukota (DKI) kepada Sekretaris Jenderal Departemen Pertambangan dan Energi, karena telah mengeluarkan Surat No. 600/ 6115/SJT/1995 tentang Persetujuan Laporan RKL dan RPL PT Freeport Indonesia Company.

Penyelesaian sengketa lingkungan melalui gugatan di peradilan tata usaha negara bertujuan agar hakim membatalkan penerbitan izin lingkungan yang tidak cermat sehingga dapat menghentikan dengan segera pencemaran lingkungan yang terjadi. Penyelesaian sengketa lingkungan melalui peradilan tata usaha negara bertujuan untuk menyelesaikan persoalan pencemaran lingkungannya.

Mengingat gugatan sengketa lingkungan melalui peradilan tata usaha negara adalah sarana efektif untuk menghentikan pencemaran lingkungan yang terjadi sehingga kedepannya harus lebih diperdayakan lagi oleh masyarakat.

\section{Rekomendasi}

Perlunya pendayagunaan peradilan tata usaha negara untuk pembatalan penerbitan izin lingkungan agar dengan segera dapat menghentikan pencemaran lingkungan.

\section{DAFTAR PUSTAKA}

Efendi, A'an, 2012, Penyelesaian Sengketa Lingkungan, Bandung: Mandar Maju. , 2010, Kewenangan Kementerian Negara Lingkungan Hidup (KNLH) Dalam Pengelolaan Lingkungan di Indonesia, Majalah Hukum dan Masyarakat, Jember: FH Universitas Jember. , 2011, Hak atas Lingkungan Hidup yang Baik dan Sehat dalam UUD 1945 dan Perbandingannya dengan Konstitusi Beberapa Negara, Bandung: Pusat Studi Kebijakan Negara Universitas Padjajaran.
, 2011, Hak atas Lingkungan Hidup yang Baik dan Sehat Dalam UUD 1945 dan Prosedur Pelaksanaannya, Jember: Jurnal Pusat Kajian Konstitusi Universitas Jember.

2011, Instrumen-Instrumen Hukum Lingkungan Sarana Pencegahan Pencemaran Lingkungan, Jurnal Hukum Supremasi, Blitar: FH Universitas Islam Balitar. , 2011, Isu Lingkungan dalam Pemilihan Umum Kepala Daerah, Jember: Jurnal Pusat Kajian Konstitusi Universitas Moch. Sroedji, Jember.

2011, Penegakan Hukum Lingkungan Administratif di Daerah: Problematika dan Pembicaraannya dalam Pemilukada, Jember: Jurnal Pusat Kajian Konstitusi Universitas Jember.

,2011, Telaah Pasal 66 Undang-Undang No. 32 Tahun 2009 tentang Perlindungan dan Pengelolaan Lingkungan Hidup (UUPPLH) terhadap Pasal 28D ayat 1 UUD 1945, Jember: Jurnal Pusat Kajian Konstitusi Universitas Moch. Sroedji.

, 2011, UUD 1945 dan Aktivitas Bisnis

Hijau, Surabaya: Jurnal Pusat Kajian Konstitusi Universitas Dr. Sutomo.

, 2012, Penyelesaian Kasus Pencemaran Lingkungan dari Aspek Hukum Lingkungan, Majalah Hukum Risalah Hukum, Samarinda: FH Universitas Mulawarman.

, 2012, Prinsip-Prinsip Pengelolaan

Pertambangan Berbasis Lingkungan Berdasar

Undang-Undang Dasar Negara Republik Indonesia Tahun 1995, Jurnal Pusat Kajian Hukum Konstitusi Universitas Janabadra. , Perizinan Lingkungan Sarana Pencegahan

Pencemaran Lingkungan, Jurnal Ilmu Hukum Qistie, Universitas Wahid Hasyim Semarang, Vol.3 No. 3, 2009.

Rahmadi, Takdir, 2003, Hukum Pengelolaan Bahan Berbahaya dan Beracun, Surabaya: Airlangga University Press.

Rangkuti, Siti Sundari, Kesamaan Persepsi terhadap Penegakan Hukum Lingkungan, Yuridika, Majalah Fakultas Hukum Unair, No. 5 Tahun 1994.

2005, Hukum Lingkungan dan Kebijaksanaan Lingkungan Nasional, Surabaya: Airlangga University Press.

, 2008, Reformasi Bidang Hukum Lingkungan, dalam Departemen Hukum Tata Negara FH Unair, Dinamika Hukum Tata 
Negara dan Hukum Lingkungan Edisi Khusus Kumpulan Tulisan dalam rangka Purnabakti Prof. Dr. Siti Sundari Rangkuti, S.H., Surabaya: Airlangga University Press.
Wijoyo, Suparto, 1999, Penyelesaian Sengketa Lingkungan, Surabaya: Airlangga University Press, Surabaya. 